\title{
Additional molecular data on the protected springsnail species Bythinella viridis (Poiret, 1801) (Gastropoda: Bythinellidae) suggest synonymy of related taxa
}

\author{
Vincent E. Prie ${ }^{1, *}$ and Xavier Cucherat ${ }^{2}$ \\ ${ }^{1}$ Research Associate, Institute of Systematics, Evolution, Biodiversity (ISYEB), National Museum of Natural History (MNHN), CNRS, \\ SU, EPHE, UA, CP 51, 57 rue Cuvier, 75005 Paris, France \\ ${ }^{2}$ Arion.idé, 10 rue Louis Aragon, 59147 Gondecourt, France
}

Received: 20 July 2021 / Accepted: 22 October 2021

\begin{abstract}
The taxonomic status of the springsnails $B$. viridis, B. carinulata and B. lancelevei remains unclear despite the molecular evidence data provided by Benke et al. (2009). Based on extensive sampling and the analysis of COI, 16S, 28S and ITS genes, we investigate analyze the genetic variability of Bythinella populations sampled within the area of occurrence of the three nominal taxa. Topotypic populations of $B$. lancelevei and $B$. viridis cannot could not be distinguished. Some of the populations included in the putative area of distribution range of $B$. carinulata form distinct supported clades, but these distinct clades are not monophyletic and the overall genetic divergence is less than the $3 \%$ barcoding gap for species of the genus the barcoding gap of c.a. $3 \%$ for Bythinella species. Therefore, we propose to synonymize these three nominal species under the name $B$. viridis (Poiret, 1801). Our results have important conservation implications, as they significantly expand the range of the protected species $B$. viridis. This species should be considered in impact studies in a large northeastern quarter of France.
\end{abstract}

Keywords: Taxonomy / molecular phylogeny / species delimitation / Bythinella carinulata / Bythinella lancelevei

\begin{abstract}
Résumé - Des données moléculaires supplémentaires sur l'espèce protégée Bythinella viridis (Poiret, 1801) (Gastropoda: Bythinellidae) suggèrent la synonymie des taxons apparentés. Le statut taxonomique des Bythinelles $B$. viridis, $B$. carinulata et $B$. lancelevei reste mal défini en dépit des données moléculaires fournies par Benke et al. (2009). Sur la base d'un échantillonnage extensif et de l'analyse des gènes COI, 16S, 28S et ITS, nous analysons la variabilité génétique des populations de Bythinelles échantillonnées au sein de la zone d'occurrence des trois taxons nominaux. Les populations topotypiques de $B$. lancelevei et $B$. viridis n'ont pas pu être distinguées. Certaines des populations incluses dans l'aire de répartition supposée de $B$. carinulata forment des clades distincts et soutenus, mais ces clades ne sont pas monophylétiques et la divergence génétique globale est inférieure au barcoding gap de $3 \%$ pour les espèces du genre Bythinella. Par conséquent, nous proposons de synonymiser ces taxons sous le nom $B$. viridis (Poiret, 1801). Nos résultats ont des implications importantes en termes de conservation, puisqu'ils élargissent considérablement l'aire de distribution de l'espèce protégée $B$. viridis. Cette espèce devrait être prise en compte dans les études d'impact dans un grand quart nord-est de la France.
\end{abstract}

Mots clés : Taxonomie / phylogénie moléculaire / délimitation d'espèces / Bythinella carinulata / Bythinella lancelevei

The springsnail Bythinella viridis (Poiret, 1801) is endemic to France and protected by French law. According to available data, this species is restricted to a few springs in the Oise and Marne River catchments (Falkner et al., 2002). Bythinella carinulata (Drouët, 1867), also protected by French law was described from a large area around the city of Dijon, including

\footnotetext{
${ }^{*}$ Corresponding author: prie.vincent@gmail.com
}

the Aube and Haute-Marne departments, i.e., south of the distribution area of $B$. viridis. B. lancelevei Locard, 1884 was described from specimens collected in the lower Seine, a few tens of kilometers away from the sea, about $200 \mathrm{~km}$ west of the distribution area of $B$. viridis.

Bythinella carinulata (Drouët, 1867) is revalidated by Boeters (1998) from material collected in the upper Seine drainage. $B$. lancelevei is morphologically very close, if not identical, to B. viridis, but Falkner et al. (2002) consider it as a 
distinct species, based on the fact that it occurs $200 \mathrm{~km}$ away from the nearest localities of $B$. viridis. For the establishment of the IUCN red list, Bichain and Prié (2010) considered $B$. lancelevei as a synonym of $B$. viridis based on the molecular results of Bichain (2007a,b). Benke et al. (2009) published a review of the phylogeography of Bythinella species throughout Europe based on molecular data and their results suggest $B$. viridis and $B$. lancelevei should be synonymized, but the authors do not discuss the taxonomic implications of their results. In the absence of a taxonomic conclusion by Benke et al. (2009), Gargominy et al. (2011) maintained B. lancelevei and B. carinulata as distinct species in the French checklist. More recently, Pouchard and Bichain (2013) and Pouchard (2018) have published new localities for $B$. lancelevei. Finally, the two electronic taxonomic registers TAXREF (French register, Gargominy et al., 2020) and MolluscaBase (global register of molluscs, MolluscaBase 2021) follow the validity of that species.

In this note we give additional molecular data from 15 localities from north-east France and address the question of the taxonomic status of the currently valid species in the Bythinella viridis group.

Family Bythinellidae Locard, 1893

Genus Bythinella Moquin-Tandon, 1856

Bythinella viridis (Poiret, 1801)

Orignal combination: Bulimus viridis Poiret, 1801: 45-46.

Type locality: « Le ruisseau qui tombe en cascade de la montagne en bas de laquelle est situé le moulin de Veau, proche de Chartreuve [nowadays Chery-Chartreuve, in the Aisne department] »

Distribution: according to Boeters (1998) and Falkner et al. (2002), restricted to a few springs in the Oise and Marne Rivers catchments. The type locality of $B$. viridis is unambiguous and still hosts the species (locality 1 in Tab. 1). COI sequences from topotypes are provided by Benke et al. (2009) and Bichain et al. (2007b); ITS sequence fragments come from Bichain et al. (2007a). Bythinella viridis is protected by French law and categorized as ENBlab(iii,iv) +2ab(iii,iv) by the IUCN red list (Bichain and Prié, 2010).

\section{Bythinella lancelevei Locard, 1884}

Orignal combination: Bythinella lancelevei Locard, 1884.

Type locality: Villequier (Seine-Maritime), « (...)sous les pierres submergées du ruisseau du chemin du Nord, qui coule vers la Seine ».

Distribution: according to Falkner et al. (2002), known only from the type locality, but Pouchard and Bichain (2013) and Pouchard (2018) give a few more locations in the Eure and SeineMaritime departments. Specimens of $B$. lancelevei collected from the spring of La Roquette in Villequier are here considered as topotypes. COI, $16 \mathrm{~S}$ and $28 \mathrm{~S}$ genes fragments were amplified by Benke et al. (2009). Additional COI gene fragments from three specimens sampled in Fort-Movil, about $30 \mathrm{~km}$ south-west of the type locality, were included in the analysis (Fig. 1, Tab. 1).

Bythinella lancelevei was considered as a synonym of $B$. viridis by Germain (1931), but re-established by Falkner et al. (2002). B. lancelevei is considered synonym of $B$. viridis by the IUCN red list (Bichain and Prié, 2010).

Bythinella carinulata (Drouët, 1867)

Orignal combination: Hydrobia carinulata Drouët, 1867: 90-91.
Type locality: « Habite les sources au pied de la Côte (calcaire jurassique), sur les pierres : fontaine de Larrey, près Dijon (type)! source de la Norges ! la Douix, à Chatillon-sur-Seine !... (...) Je l'ai recueilli dans l'Aube et la Haute Marne dans les mêmes circonstances $»$.

$B$. carinulata has five recognized subjective synonyms.

- Turbo griseus Vallot, 1801. Vallot (1801) does not give any precise type locality, but the original publication deals with the Côte d'Or department). The name Turbo griseus was considered nomen oblitum by Boeters (1974) and Falkner et al. (2002) considered that the strict application of the priority was not advisable in this case.

- Paludinella turgidula Paladilhe, 1869. The type locality is Billy-les-Chanceaux (source de la Seine) and Paladilhe (1869) adds « dans le département de l'Aube, aux environs de Bar-sur-Seine et des Riceys ».

- Paludinella scalarina Paladilhe, 1876. Châtillon-sur-Seine (Côte d'Or) and Boutigny (Seine-et-Marne).

- Bythinella burgundina Locard, 1893. Locard (1893) attributes this name to Beaudouin (1890) [sic], probably referring to Beaudouin (1888). This nominal species is known from pits in Châtillon-sur-Seine (Côte d'Or).

- Bythinella viridiformis R. Bernasconi, 1989. The type locality is Barbirey-sur-Ouche (Côte-d'Or). Bernasconi (1989) gives a large distribution including the Plateau de Langres and the departements of the Côte-d'Or, Haute-Marne, Haute-Saône and Vosges.

Boeters (1998) re-established the name Bythinella carinulata and considered Paludinella turgidula Paladilhe, 1869, from Ricey and Bar-sur-Seine (Aube department) as a junior synonym. According to Falkner et al. (2002), the specimens from Barbirey-sur-Ouche (Côte-d'Or department) studied by Bernasconi (1989) would also belong to $B$. carinulata, although Bernasconi himself eventually considered them as synonyms of $B$. viridis (Bernasconi com. pers. in Falkner et al., 2002). B. carinulata viridiformis is considered by Fauna Europaea as synonym of B. carinulata, but is not considered in MolluscaBase.

Distribution: Drouët (1867) gives a wide range for this species, encompassing the drainages of the Seine and the Rhône Rivers (Fig. 1).

The type locality of Bythinella carinulata ("fontaine de Larrey, près Dijon") should be the actual Fontaine d'Ouches, which springs north of the Larrey district, in the city of Dijon. No Bythinella live in this spring anymore (E. Farat, com. pers.). According to Boeters (1998), the populations from Bar-sur-Seine are conspecific with B. carinulata. Benke et al. (2009) used specimens collected in Julysur-Sarce, which lies about five kilometers away from Bar-surSeine, and considered them as B. carinulata. This later locality can be used as ergonymotope (sensus Frétey et al., 2018) for this species. We used the COI, 16S and 28S genes fragments amplified by Benke et al. (2009) for B. carinulata. Bythinella carinulata is protected by French law and categorized as EN B1ab(iii)+2ab(iii) by the IUCN red list (Prié, 2010).

\section{Material and methods}

Morphological characters and anatomy are not relevant for species delimitation in the Bythinella genus 
V.E. Prie and X. Cucherat: Knowl. Manag. Aquat. Ecosyst. 2021, 422, 36

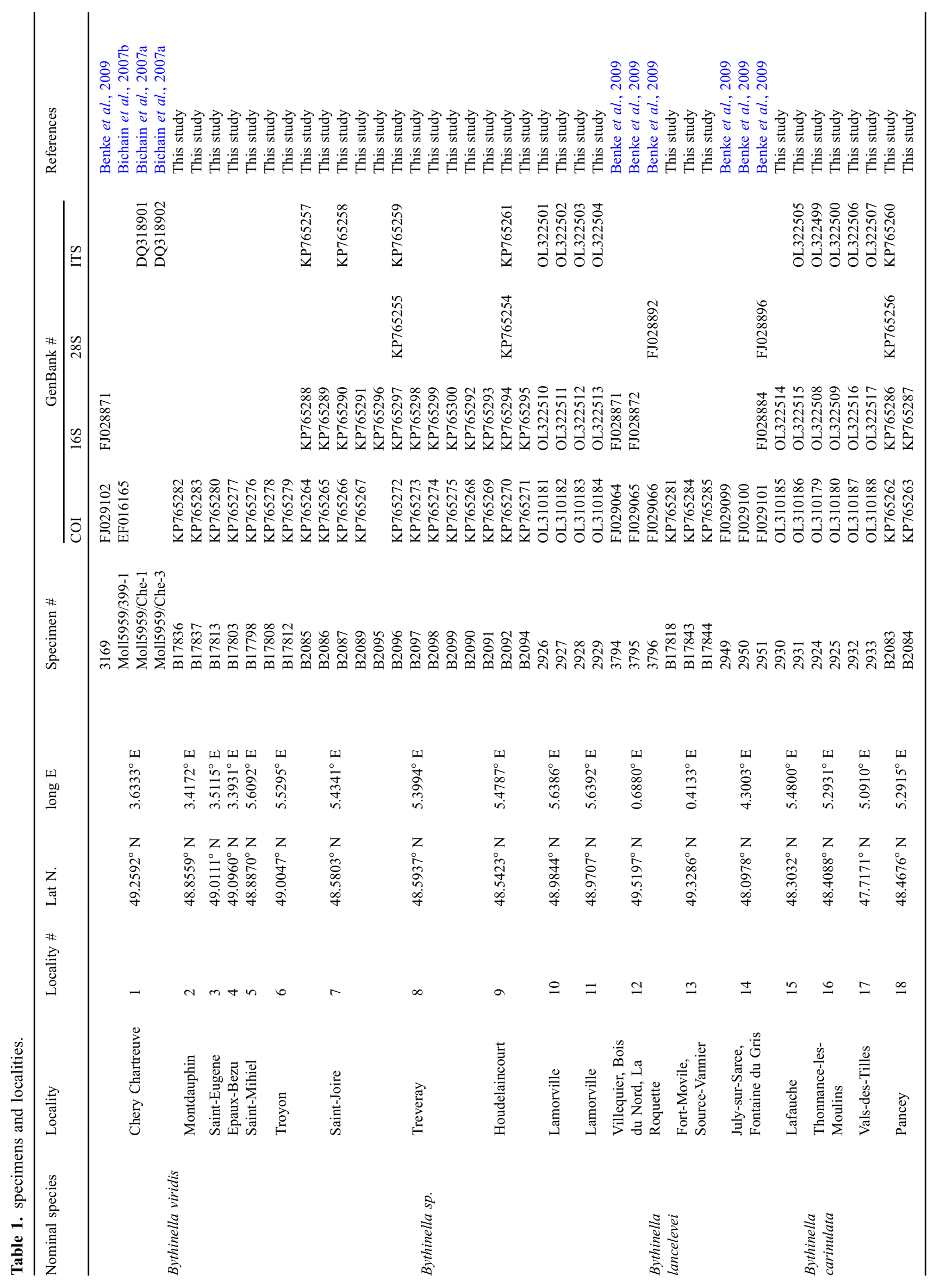




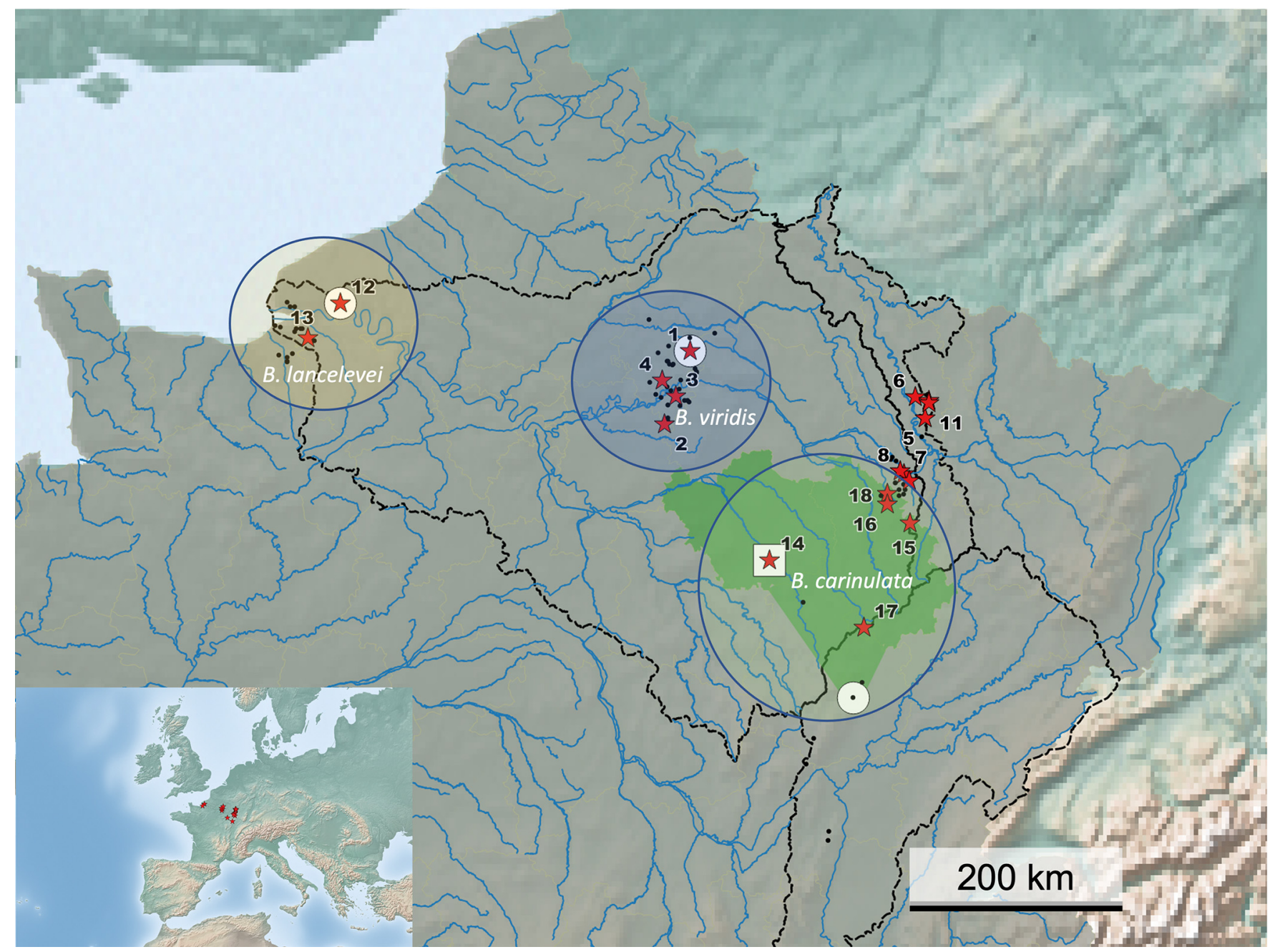

Fig. 1. Known Bythinella records in the area (black dots), sampled sites (red stars) and putative distribution of the three nominal species. Sampling sites numbers refer to Table 1. Circles: type localities; square: ergonymotope for $B$. carinulata. The green polygon refers to the distribution of B. carinulata according to Drouët (1867). Black dotted lines represent the major watershed limits (Seine, Meuse and Rhône drainages). Scale bar: $100 \mathrm{~km}$.

(Bichain et al., 2007a, b). We thus relied on the genetic distances between specimens to delimit species. Following a barcoding approach, we used the pairwise distribution of the genetic distances calculated with the Barcode gene COI to identify a gap in the distribution, referred to as the "barcoding gap" (Puillandre et al., 2012), between intra and interspecific distances. A total of 1074 COI sequences of Bythinella species downloaded from GenBank (Dataset 1) were used to estimate the barcoding gap (supplementary material 1). MEGA 10.05 (Tamura et al., 2011) was used to calculate the p-distances (following Srivathsana and Meier, 2012) between each pair of specimens. The distribution of the genetic distances was then calculated using an excel sheet (Supplementary material 1). The COI barcoding gap for the Bythinella genus was found to be around 3\%. This result is congruent with the species level divergence observed in other Bythinella taxonomic papers (Bichain et al., 2007a, b; Prié and Bichain, 2009).

We analyzed a total of 48 specimens from 18 localities (Tab. 1). Extraction and amplification were performed using standard protocols (ex. Bichain et al., 2007b). Total genomic DNA was extracted using the Qiagen DNA Mini Kit and following the manufacturer's protocol. Universal primers were used for the amplification of 16S (Palumbi et al., 1991) and 28S (Park and O'Foighil, 2000). For ITS and COI, we used the primers designed by Bichain et al. (2007a, b).

Sequences were automatically aligned using CLUSTALW multiple alignments implemented in BIOEDIT 7.2.5 (Hall, 1999). The accuracy of automatic alignments was confirmed by eye. Only a few gaps, unambiguously aligned, were inferred for the $28 \mathrm{~S}$, ITS and $16 \mathrm{~S}$ genes: they were conserved for the analyses.

We obtained 34 sequences for the COI gene (Tab. 1), resulting after alignment in a $557 \mathrm{bp}$ fragment. Seven additional sequences downloaded from GenBank were included the dataset (two sequences for both $B$. viridis and $B$. lancelevei, three sequences for B. carinulata). A total of 25 sequences were obtained for the $16 \mathrm{~S}$ gene, and four additional sequences were included in the dataset (two for $B$. viridis, one 


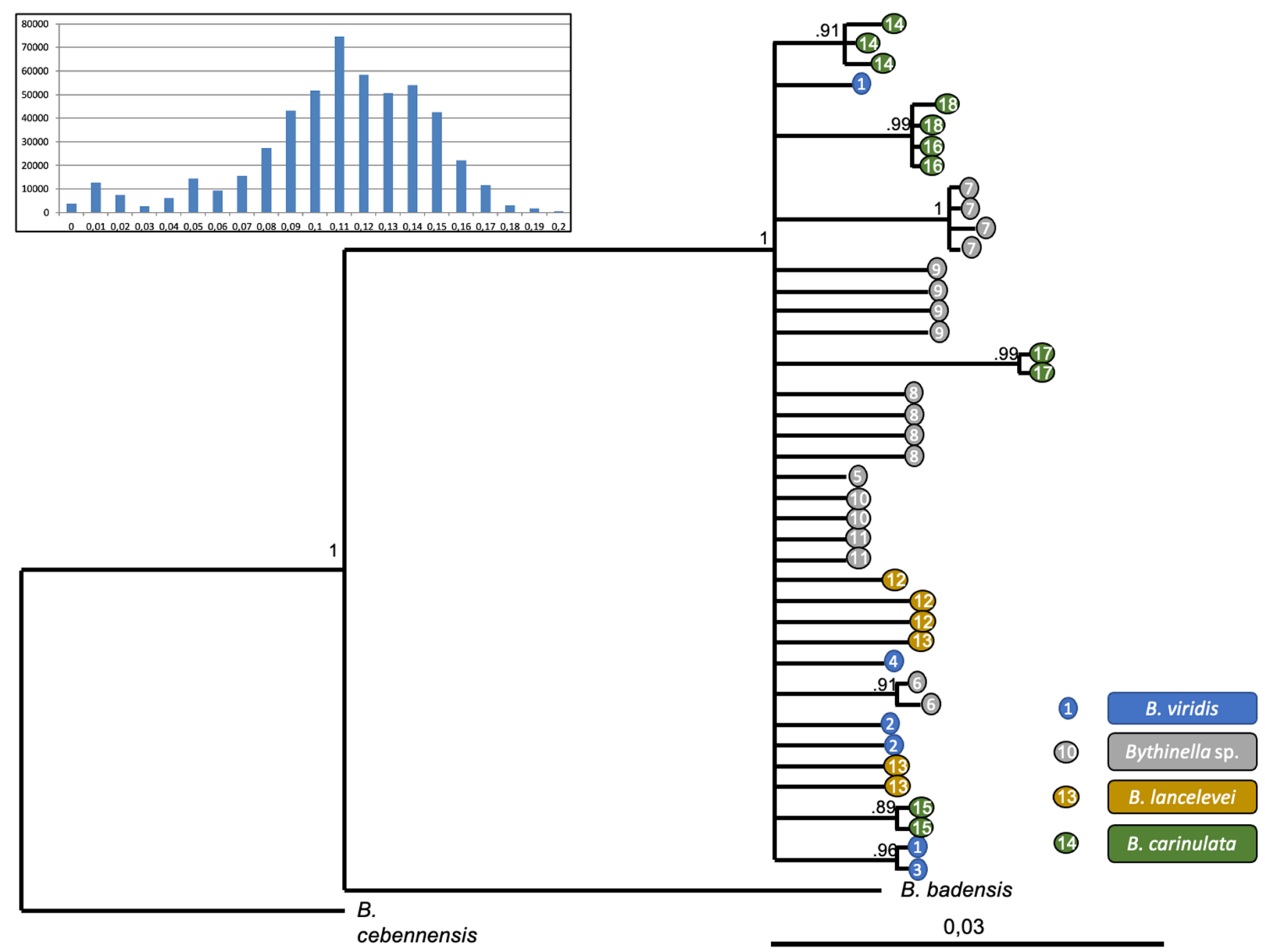

Fig. 2. Phylogenetic tree based on Bayesian inference, using the COI gene. Only posterior probabilities $>0.8$ are shown. Numbers refer to the sampled localities (Fig. 1, Tab. 1). Scale bar (0.3) indicate the minimum inter-specific genetic divergence for the COI gene (barcoding gap). Top left: distribution of the genetic divergence within the genus Bythinella illustrating the barcoding gap.

for B. carinulata and one for B. lancelevei), resulting after alignment in a $502 \mathrm{bp}$ fragment. Three sequences were obtained for the $28 \mathrm{~S}$ gene, and two additional sequences are available from GenBank (one for B. lancelevei and one for $B$. carinulata). After alignment, $28 \mathrm{~S}$ gene sequences resulted in a 799 bp fragment. Fourteen sequences were obtained for the ITS gene, and two additional sequences (B. viridis) were downloaded from GenBank. After alignment, ITS gene sequences resulted in a $267 \mathrm{bp}$ fragment.

For phylogenetic analyses of the COI gene fragment, B. badensis Boeters, 1981 and B. cebennensis (Dupuy, 1849) were chosen as outgroups, following the results of Benke et al. (2009). Bayesian analysis were performed running two parallel analyses in MRBAYES V 3.1.2 (Huelsenbeck et al., 2001), each consisting of two Markov chains of 5000000 generations each, sampled every 1000 generations. We defined three partitions (one for each codon position). Convergence of the analysis was checked using TRACER V 1.7.1 (Rambaut et al., 2018); all ESS values were $>200$ (default burnin). A consensus tree was then calculated after omitting the first
$10 \%$ trees as burn-in. Chains had converged after 3.000 .000 generations.

\section{Results}

COI gene phylogeny of the genus Bythinella (based on Dataset 1) confirmed the monophyly of all studied populations (results not shown). Within this clade, corresponding to clade V of Benke et al. (2009), B. viridis and B. lancelevei topotypes could not be distinguished. Some populations of the putative B. carinulata formed distinct supported clade, but these were not monophyletic (Fig. 2). These results confirm those of Benke et al. (2009). The 16S gene was little variable (overall $p$-distance $=0.01)$. The topotypes of $B$. viridis and $B$. lancelevei shared the same haplotype for this gene. Regarding the nuclear genes, all the specimen studied shared the same haplotype for the $28 \mathrm{~S}$ fragment. The ITS gene fragment was a bit more variable (overall $p$-distance $=0.07$ ). Topotype specimens of $B$. viridis had an insertion (AGA) in 
position 99 and a $\mathrm{G}$ in position 238. For all gene fragments, nominal species and newly sequenced specimens could not be distinguished.

Average genetic distance for COI gene was 0.0093 . Maximum distance observed was 0.0250 between specimens of $B$. carinulata from July-sur-Sarce (ergonymotope, locality 14) and specimens presumably of the same species from Vals-des-Tilles (locality 17, the closest locality to the type locality in Dijon) The genetic distance between $B$. viridis, $B$. lancelevei and $B$. carinulata was below the barcoding gap threshold, suggesting that all the specimens analyzed belong to the same species.

\section{Discussion}

$B$. viridis is the oldest name available. In our opinion, it makes no doubt that $B$. lancelevei is a junior synonym of $B$. viridis. There is no morphological argument to jeopardize the genetic data. B. lanceleve $i$ was considered a distinct species by Falkner et al. (2002) only based on one argument: the geographic distance from $B$. viridis. However, (i) the known populations of $B$. lancelevei are in the same drainage as the known populations of $B$. viridis (Seine River drainage) and (ii) some localities may have been overlooked in between. The apparent isolation between the populations of the lower Seine (B. lancelevei) and the populations from the upper Seine drainage (B. viridis) could result from human impact or other recent geographic isolation, but is very likely a collection bias. Regarding $B$. carinulata, although all the specimens studied formed a distinct clade in $\mathrm{COI}$ and $16 \mathrm{~S}$, genetic divergence was very low, suggesting it should also be synonymized with $B$. viridis.

In the absence of contradictory evidence, we propose to synonymize $B$. viridis, $B$. lancelevei and $B$. carinulata under the name Bythinella viridis (Poiret, 1891). As B. viridis is protected in France, conservation measures and consideration in impact studies should apply throughout its the entire range, i.e., from the lower Seine west (Fig. 1, 13) to the Meuse drainage east (Fig. 1, 11) and down to the upper Rhône south (Fig. 1, 17).

Acknowledgments. This study was performed with financial support of the DREAL Picardie, and the Parc naturel régional de Lorraine. Sequencing of the specimens was performed by Lise-Marie Pigneur (Université de Lièges), Stephane Dreano (Université de Rennes I) and Sebastian Berg (Animal Ecology and Systematics, Justus Liebig University Giessen).

\section{References}

Beaudouin J. 1888. Faune malacologique vivante de l'arrondissement de Châtillon-sur-Seine (Côte-d'Or). Bull Soc Malac France 5: 377-423.

Benke M, Braendle M, Albrecht C, Wilke T. 2009. Pleistocene phylogeography and phylogenetic concordance in cold-adapted spring snails (Bythinella spp.). Mol Ecol 18: 890-903.

Bernasconi R. 1989. Die Bythinella der Süd-und West-Schweiz und von Ost-Frankreich (Gastropoda: Prosobranchia: Hydrobioidea). Folia malacologia 3: 33-54.

Bichain J-M., Boisselier-Dubayle M-C., Bouchet P, Samadi S. 2007a. Delimiting species in the genus Bythinella (Mollusca:
Caenogastropoda: Rissooidea): a first attempt using molecular and morphometrics tools. Malacologia 49: 291-311.

Bichain J-M, Gaubert P, Samadi S, Boisselier-Dubayle M-C. $2007 \mathrm{~b}$. A gleam in the dark: Phylogenetic species delimitation in the confusing spring-snail genus Bythinella Moquin-Tandon, 1856 (Gastropoda: Rissooidea: Amnicolidae). Mol Phyl Evol 45: 927-941.

Bichain J-M, Prié V. 2010. Bythinella viridis. The IUCN Red List of Threatened Species. Version 2014. 3. <www.iucnredlist.org >. Downloaded on July 2021.

Boeters HD. 1998. Mollusca: Gastropoda: Superfamilie Rissooidea. In Schwoerbel J, Zwick P, eds. Süßwasserfauna von Mitteleuropa (Begründet von A. Brauer), G Fischer, Stuttgart, 76p.

Boeters HD. 1974. Die Gattung Bythinella und die Gattung Marstoniopsis in Westeuropa, I Westeuropaïsche Hydrobiidae, 4 (Prosobranchia). Malacologia 14: 271-285.

Drouët H. 1867. Mollusques terrestres et fluviatiles de la Côte-d'Or, Say, Paris, 126 p.

Falkner G, Ripken TEJ, Falkner M. 2002. Mollusques continentaux de la France. Liste de référence annotée et bibliographie. Patrimoines Naturels 52: 1-350.

Frétey T, Dewynter M, Ohler A-M. 2018. Onymotopes in zoological nomenclature: some additional terms, with fixation of a lectonymotope for Xenopus petersii Bocage, 1895 (Amphibia, Anura). Bionomina 13: 37-50.

Gargominy O, Prié V, Bichain J-M, Cucherat X, Fontaine B. 2011. Liste de référence annotée des mollusques continentaux de France. MalaCo 7: 307-382.

Hall TA. 1999. BioEdit: a user-friendly biological sequence alignment editor and analysis program for Windows 95/98/ NT. Nucleic Acids Symp Ser 41: 95-98.

Huelsenbeck JP, Ronquist F, Hall B. 2001. MrBayes: Bayesian inference of phylogenetic trees. Bioinformatics 17: 754-755.

Locard A. 1893. Les Coquilles des eaux douces et saumâtres de France. Description des familles, genres et espèces, Paris, 327p.

Paladilhe A. 1869. Descriptions de quelques Paludinidées, Assiminidées et Mélanidées nouvelles. Rev Mag Zool 21: 273-284.

Palumbi S, Martin A, Romano S, McMillan WO, Stice L, Grabowski G. 1991. The Simple Fool's Guide to PCR, University of Hawaii, Honolulu, 45p.

Park J-K, O'Foighil D. 2000. Sphaeriid and Corbiculid clams represent separate heterodont bivalve radiations into freshwater environments. Mol Phyl and Evol 14: 75-88.

Pouchard C, Bichain J-M. 2013. Nouvelles localités pour Bythinella lancelevei Locard, 1884 (Gastropoda, Rissoidea, Bythinellidae) en Haute-Normandie (Eure, Seine-Maritime) et proposition de catégorisation UICN. MalaCo 9: 485-497.

Pouchard C. 2018. Contribution à la connaissance de Bythinella lancelevei Locard, 1884 (Gastropoda, Littorinimorpha, Bythinellidae): une présence avérée en Pays d'Auge établit une distribution plus occidentale et plus méridionale de l'espèce. Mala Co 14: 17-20.

Prié V, Bichain J-M. 2009. Phylogenetic relationships and description of a new stygobite species of Bythinella (Mollusca, Gastropoda, Caenogastropoda, Amnicolidae) from southern France. Zoosystema 31: 987-1000.

Prié V. 2010. Bythinella carinulata. The IUCN Red List of Threatened Species 2010: e.T3385 A9814892. https://dx.doi.org/10.2305/ IUCN.UK.2010-4.RLTS.T3385A9814892.en. Downloaded on 23 September 2021.

Puillandre N, Lambert A, Brouillet S, Achaz G. 2012. ABGD, Automatic Barcode Gap Discovery for primary species delimitation. Mol Ecol 21: 1864-77. 
V.E. Prie and X. Cucherat: Knowl. Manag. Aquat. Ecosyst. 2021, 422, 36

Rambaut A, Drummond AJ, Xie D, Baele G, Suchard MA. 2018. Posterior summarisation in Bayesian phylogenetics using Tracer 1.7. Systematic Biology 67: 901-904.

Srivathsana A, Meier R. 2012. On the inappropriate use of Kimura-2parameter $(\mathrm{K} 2 \mathrm{P})$ divergences in the DNA-barcoding literature. Cladistics 28: 190-194.
Tamura K, Peterson D, Peterson N, Stecher G, Nei M, Kumar S. 2011. MEGA5: molecular evolutionary genetics analysis using maximum likelihood, evolutionary distance, and maximum parsimony methods. Mol Biol Evol 28: 2731-2739.

Vallot JN. 1801. Exercice sur l'histoire naturelle. École centrale du département de la Côte-d'Or, Dijon, 8p.

Cite this article as: Prie VE, Cucherat X. 2021. Additional molecular data on the protected springsnail species Bythinella viridis (Poiret, 1801) (Gastropoda: Bythinellidae) suggest synonymy of related taxa. Knowl. Manag. Aquat. Ecosyst., 422, 36. 